Louisiana State University

LSU Digital Commons

Faculty Publications

Department of Oceanography \& Coastal

Sciences

$1-1988$

\title{
Marsh Management Plans in Practice: Do they work in coastal Louisiana, USA?
}

James H. Cowan Jr.

R. Eugene Turner

euturne@lsu.edu

Donald R. Cahoon

Follow this and additional works at: https://digitalcommons.Isu.edu/oceanography_coastal_pubs

\section{Recommended Citation}

Cowan, J. H., Turner, R., \& Cahoon, D. R. (1988). Marsh Management Plans in Practice: Do they work in coastal Louisiana, USA?. Environmental Management, 12 (1), 37-53. Retrieved from

https://digitalcommons.Isu.edu/oceanography_coastal_pubs/161

This Article is brought to you for free and open access by the Department of Oceanography \& Coastal Sciences at LSU Digital Commons. It has been accepted for inclusion in Faculty Publications by an authorized administrator of LSU Digital Commons. For more information, please contact ir@lsu.edu. 


\section{Marsh Management Plans in Practice: Do They Work in Coastal Louisiana, USA?}

\author{
JAMES H. COWAN, Jr.* \\ R. EUGENE TURNER \\ DONALD R. CAHOON \\ Coastal Ecology institute \\ Center for Wetland Resources \\ Louisiana State University \\ Baton Rouge, Louisiana 70803-7503, USA
}

ABSTRACT / Louisiana's coastal wetlands represent about $41 \%$ of the nation's total and are extensively managed for fish, fur, and waterfowl. Marsh management plans (MMPs) are currently used to avoid potential user conflicts and are believed to be a best management practice for specific management goals. In this article. we:define MMPs and examine their variety, history, impacts, and future.

A MMP is an organized written plan submitted to state and federal permitting agencies for approval and whose purpose is to regulate wetland habitat quantity and quality (control land loss and enhance productivity). MMPs are usually implemented by making structural modifications in the marsh, primarily by using a variety of water control structures in levees to impound or semi-impound managed areas. It appears that MMPs using impoundments are only marginally successful in achieving and often contradict management goals. Although $20 \%$ of coastal Louisiana may be in MMPs by the year 2000 , conflict resolution of public and private goals is compromised by a surfeit of opinion and dearth of data and experience. Based on interpretation of these results, we believe the next phase of management should include scientific studies of actual impacts, utilization of postconstruction monitoring data, inventory of existing MMPs, development of new techniques, and determination of cumulative impacts.
Louisiana's coastal wetlands are about $41 \%$ of the nation's total (Turner and Gosselink 1975) and comprise one of the most extensive coastal wetland management zones in the United States. Development of Louisiana's coastal resources has been extensive during this century and, in some years, almost onethird of the US Army Corps of Engineers dredge and fill permits are issued in Louisiana (Mager and Hardy 1986). Consequently, the potential for user conflict is high and various resource management practices have been developed in Louisiana to cope with user demands. What management practices are, and are not, working in Louisiana may have application elsewhere. In this article, we examine various aspects of one wetland management practice common in coastal Louisiana, the marsh management plan (MMP).

A MMP is defined as an organized written plan submitted to state and federal permitting agencies by owners of coastal wetlands seeking approval to manage their land. The purpose of a MMP is to regulate and/or maintain wetland habitat quantity and quality. The plans are usually implemented by making structural modifications in the marsh, primarily by

KEY WORDS: Wetlands; Marsh management; Louisiana; Impoundment; Water control structures

\footnotetext{
*Author to whom correspondence should be addressed.
}

using levees and water control structures to create impounded or semi-impounded management areas, as a means of regulating (a) water flow duration, frequency, and depth, or (b) animal and plant population size and composition. A MMP may also include a schedule to burn the marsh. The implementation of MMPs has raised several issues concerning their effectiveness in controlling land loss, accessibility to managed areas by estuarine organisms, and the privatization of navigable waterways. This has led, at times, to strained relations between coastal resource users (that is, recreational and commercial fishermen, oil/gas industry, and so on), landowners, and state/federal regulatory personnel. Therefore, this article provides: (a) a review of the permitting authority and guidelines by which MMPs are developed, including impact assessments (land loss control, estuarine accessibility) and monitoring; (b) a brief description of impoundment usage categories and functional types, and a discussion of the feasibility of impounding wetlands as a management practice; (c) an evaluation of impoundments as a useful marsh management practice in Louisiana's Chenier Plain, based on quantitative land loss data and relevant information from state and federal agency personnel and corporate and private landowners; and (d) an assessment of the effectiveness and efficacy of the permitting process and regulatory policies. We begin by briefly explaining geographic, geologic, and hydrologic factors leading to coastal Louisiana wetland 
formation, stability, and decline, as well as wetland functions. We then discuss wetland management goals, which are generally to regulate land loss, water, and plant and animal distribution and abundance. Finally, we focus on the formal MMP submitted in state and federal permit applications, including the history of MMPs, specific examples emphasizing the Chenier Plain, impacts, and results. Recommendations and cautionary summaries are included.

\section{Wetland Formation and Loss in Coastal Louisiana}

Louisiana's $1.8 \times 10^{6}$ ha of coastal wetlands are formed from the deltaic and marginal deltaic (chenier) plains of the Mississippi and Atchafalaya Rivers (Figure 1). The current geologic conditions in the coastal zone reflect the 16 major deltaic episodes of alternating growth and decay that occurred over the past 6000 years prior to the emerging Atchafalaya River Delta (reviews of the modern history of the Louisiana coast are available; for example, Price 1954, Fisk 1960, Frazier 1967, Coleman 1976, Turner 1985). During these cycles, sediment sorting, dewatering, compaction, and consolidation resulted in wetland areas of greater and lesser susceptibility to subsidence and land loss. Until recently, biological and physical factors have been nearly in balance along the Louisiana coast, resulting in net wetland gain with episodes of localized wetland loss. Currently, however, the sediment deposited by riverine systems or accumulated by biological processes appears to be less than necessary to match sea level rise, subsidence, and land loss (Turner 1985, Walker and others 1987). The overall land loss rate is about $0.8 \%$ annually $\left(130 \mathrm{~km}^{2} /\right.$ year), and is increasing geometrically with time (Gagliano and others 1981, Turner 1985, Walker and others 1987). Virtually all occurs as wetland loss. Recent studies have shown that accelerated losses in these areas may be caused in part by direct human environmental alterations resulting in hydrologic modifications, including oil and gas canal dredging, spoil banks, and levees, which restrict or eliminate regular overbank flooding (Davis 1973, Gosselink and others 1979, Craig and others 1980, Turner and others 1982, Turner 1985, Day and others 1986).

\section{Marsh Management Plans}

It was not until the early 1970 s that wetland management and coastal land loss in Louisiana began to receive special attention by researchers and public officials. During the past 15 years, the investigation of
Louisiana's coastal wetland ecosystem has increased, and state officials have developed and proposed actions designed to reduce land loss and its impacts on coastal resources (Spicer and others unpublished). These actions include construction of controlled freshwater diversions along the Mississippi River, regulation of dredge and fill activities, creative use of dredge spoil to create impoundments, and enhancing land building in the Atchafalaya River Delta (Day and Craig 1982, Day and others 1986, Spicer and others unpublished).

The use of impoundments is becoming increasingly popular with coastal landowners. These projects attempt to reduce saltwater intrusion and the conversion of land to open water (land loss), improve vegetation and fish and wildlife habitats, and support mineral exploration, or urbanization. These projects have traditionally involved the installation of levees, earthen plugs, weirs, flap-gates, and other structures aimed at controlling water level in management areas.

Some other structural components used in marsh management include backfilling canals, shoreline stabilization techniques, and semi-impoundments. For this report, the term impounded means enclosed parcel of land or water rather than a strict hydrologic reference to a confined body of water. A marsh that is completely or partially hydrologically isolated from the surrounding ecosystem, either naturally or by artificial leveeing, is considered impounded. Other, nonstructural marsh management practices include marsh burning, aquatic weed control, and revegetation of marsh by planting (Spicer and others unpublished). Weirs and other water control structures may inhibit land loss and increase wildlife and fish habitat by reducing saltwater intrusion and stabilizing water levels within the management area (Davidson and Chabreck 1983. Day and others 1986). Negative impacts encountered in structural marsh management practices, particularly in impounded marshes, include the exclusion of some species of vegetation, fish, and wildlife, alteration of hydrologic regimes and nutrient cycles, reduction of public access and rights of way, and restriction of estuarine organism movement (Spicer and others unpublished). Land loss may increase as well (Turner and Neill 1983, Day and others 1986).

\section{Guidelines and Permitting in Louisiana}

\section{Legislative Authority}

Because of the potential impacts of individual or corporate entities on public resources, local/state/federal regulatory authorities currently require permits for implementation of MMPs in the Louisiana coastal 

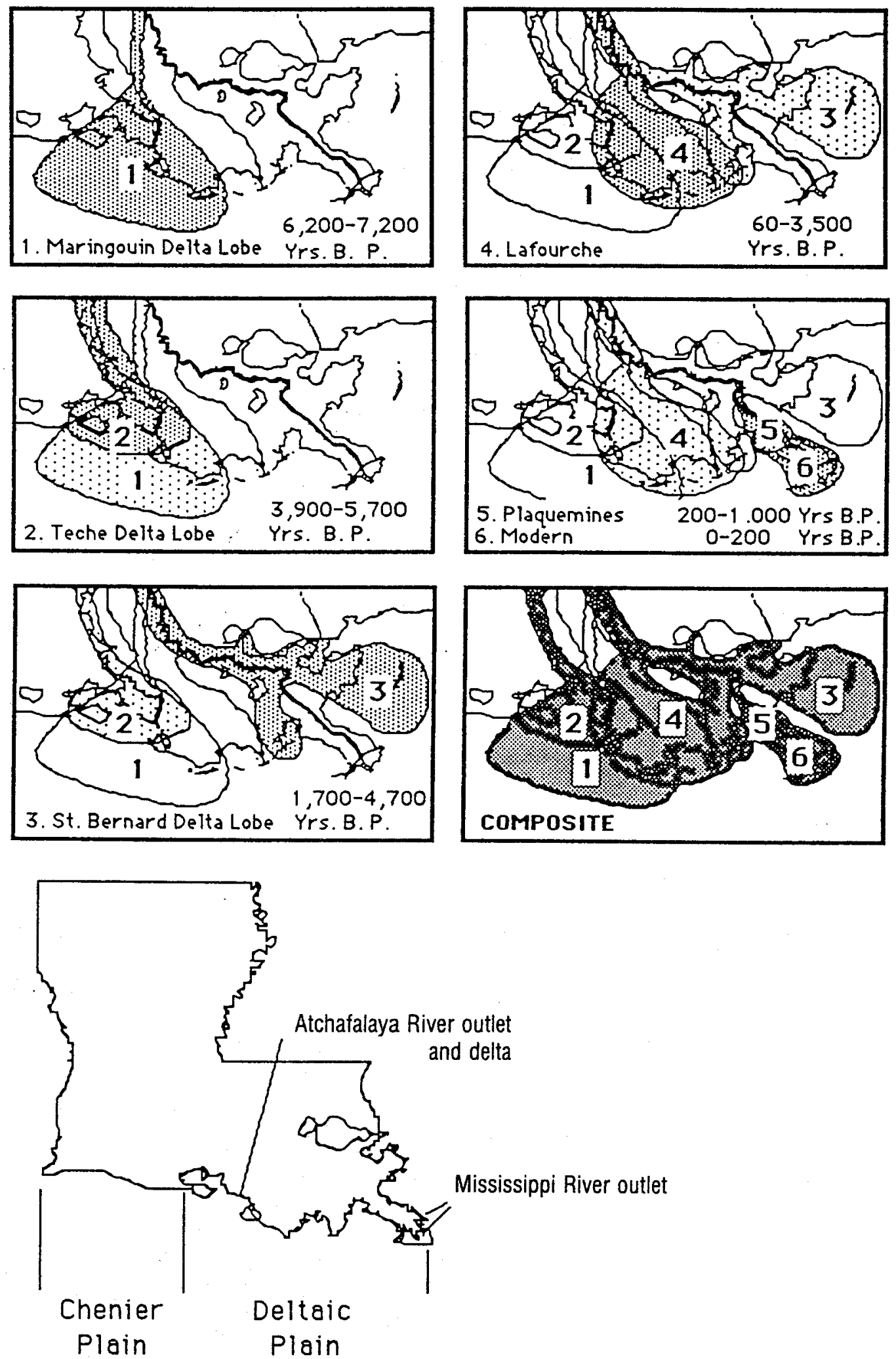

Figure 1. Coastal Louisiana, the deltaic and chenier plains: location of the major delta lobes and geographic loci. 
Table 1. Regulatory authority ${ }^{\mathrm{a}}$ overseeing development activities in the Louisiana coastal zone.

\begin{tabular}{|c|c|c|c|c|}
\hline \multirow[b]{2}{*}{ Type of authority } & \multicolumn{2}{|c|}{ State } & \multicolumn{2}{|c|}{ Federal } \\
\hline & Agency & Mandate & Agency & Mandate \\
\hline Permitting & CMD/LDNR & Coastal resources & USACOE & $\begin{array}{l}\text { Coastal resources, } \\
\text { navigation }\end{array}$ \\
\hline Commenting ${ }^{b}$ & $\begin{array}{l}\text { LDWF } \\
\text { LDEQ } \\
\text { DSL/LDNR } \\
\text { Parish CZM }\end{array}$ & $\begin{array}{l}\text { Wildlife and fisheries } \\
\text { Air/water quality } \\
\text { State property right } \\
\text { Local coastal zone } \\
\text { management, local } \\
\text { zoning }\end{array}$ & $\begin{array}{l}\text { USFWS } \\
\text { NMFS } \\
\text { SCS } \\
\text { USEPA }\end{array}$ & $\begin{array}{l}\text { Wildlife and fisheries } \\
\text { Marine fisheries } \\
\text { Soil resources } \\
\text { Wetland resources }\end{array}$ \\
\hline
\end{tabular}

a CZM, coastal zone management; LDEQ, Louisiana Department of Environmental Quality; LDNR, Louisiana Department of Natural Resources; CMD/LDNR, Coastal Management Division, LDNR; DSLLDNR, Division of State Lands, LDNR; LDWF, Louisiana Department of Wildlife and Fisheries; NMFS, National Marine Fisheries Service; SCS, US Soil Conservation Service; USACOE, US Army Corps of Engineers; USEPA, US Environmental Protection Agency; and USFWS, US Fish and Wildlife Service.

${ }^{b}$ Commenting agencies have the recourse to resolve conflicts of opinions. If the permitting agency decides to issue a permit over the objection of a commenting agency, both state and federal governments have in-house appeals procedures to resolve such disagreements.

zone. The regulatory authority overseeing the development of Louisiana's coastal resources is summarized in Table 1. An applicant wishing to develop a MMP must obtain permission from the two permitting authorities (the State of Louisiana, Department of Natural Resources, Coastal Management Division, and the US Army Corps of Engineers), but also must satisfy the policies and mandates of all the commenting agencies. Every agency has its own authorizing legislation and, therefore, its own mandate, goals, and policies (Table 1). Under authority of federal consistency regulations, the US government cannot issue MMP permits unless the State of Louisiana first issues a permit. For this reason, and out of concern for its coastal resources, the state assumes a leadership role in the development of MMPs. Therefore, we will focus on the state's role in marsh management, bearing in mind that the mandate, goals, and policies of the state differ and, at times, may conflict with those of other state and federal agencies.

\section{The State Program}

The state legislature enacted the Louisiana Coastal Resources Program (LCRP) (La. R.S. 49:213.1 et seq.) in 1978, thereby authorizing the implementation of a coastal use permitting (CUP) system for reducing user conflicts in the Louisiana coastal zone. The permitting system was implemented in 1980 and is administered by the Coastal Management Division of the Louisiana Department of Natural Resources (CMD/LDNR) (Clark and others 1983).

As the lead authority for focusing the state's wetland management efforts, the legislated goals of the LCRP are to (a) protect, develop, restore, and enhance coastal resources; (b) encourage multiuse programs; and (c) determine the future course of development and conservation in the coastal zone (LCRP/FEIS 1980). Marsh management plans must be developed with these goals in mind. Many MMPs submitted to CMD/LDNR outline measures to counteract anticipated wetland loss from a proposed activity, while others focus on measures that combat land loss and wetland deterioration caused by existing natural processes or prior development activities.

To ensure compliance with LCRP goals, a series of specific CMD/LDNR guidelines have been established for use during MMP development and permit review. Overall, LCRP goals encourage MMPs to reduce land loss and increase wetland productivity. Applicants for MMP permits must define objectives that further support LCRP goals. The following information is usually required in the MMPs: (a) area history, (b) vegetation description of the management area, (c) management strategies to be employed including water management practices and structures, (d) an outline of the monitoring program within the management area to determine whether objectives are being achieved, and (e) any known future non-marsh-management activities that are planned for the managed area (LCRP/ FEIS 1980). If applicable, information should also be included on potential environmental impacts and the proximity of the managed area to specific features such as beaches, tidal passes, historic șites, and navigation and public access facilities.

\section{Preproject Environmental Assessment and Postconstruction Monitoring}

Premanagement environmental conditions are most often assessed by on-site visual inspection of vegetational condition within the proposed management 
area by the permit applicant (landowner or, if corporate, land manager) and/or CMD/LDNR or other state and federal biologists. These visual vegetational analyses are often based on the applicant's long-term familiarity with historical premanagement conditions (D. Clark personal communication, ${ }^{1} \mathrm{M}$. Matherne personal communication ${ }^{2}$ ). Proposed MMPs developed with professional assistance [private consultants or, most frequently, the US Department of Agriculture, Soil Conservation Service (SCS)] usually include premanagement data on vegetation, soils, water level, land elevation, and salinity, as necessary to describe proposed management goals. The CMD/LDNR staff are available to give guidance to CUP applicants and also coordinate and share information with coastal landowners and other agency personnel [SCS; Louisiana Department of Wildlife and Fisheries (LDWF); US Fish and Wildlife Service (USFWS); National Marine Fisheries Service (NMFS)].

Following the implementation of a MMP, monthly environmental monitoring is required and may be done by gathering and reporting information from water quality sampling, vegetational change analysis, examination of aerial photography and land use maps, hunting and trapping records, changes in hydrology, land loss rates, and overall productivity changes or similar types of data sources. In each case, the stated management goals specific to each MMP are the primary areas where the monitoring effort should be focused (LCRP/FEIS 1980, D. Clark personal communication).

Impoundments in Marsh Management Plans: Description, Purpose, and Function

\section{Impoundments}

Almost all MMPs, either implemented or proposed to $\mathrm{CMD} / \mathrm{LDNR}$, include structural marsh management practices that result in the impoundment or semi-impoundment of wetlands in Louisiana's coastal zone. Complete hydrologic isolation of a management area is considered an impoundment, while partial confinement is considered a semi-impoundment. The area of Louisiana impoundments, by category, is summarized in Table 2 and amounts to nearly $10 \%$ of Louisiana's coastal wetlands.

\section{Impoundment Types by Usage}

Impoundments may be divided into five types that differ according to their use. These types, by usage category, are agricultural, aquacultural, fish and wildlife, urban, and unintentional.
Agricultural impoundments. In the late 1800 s and early 1900s, coastal Louisiana residents were intensely active in land reclamation efforts stemming from the passage of the Swamp Acts of 1849-50. Louisiana received approximately 3.6 million ha of this land and, because it was considered worthless, large tracts were available for purchase at low prices ( $\$ 0.16$ to $0.81 / \mathrm{ha}$ ). Thousands of hectares were diked, cleared, and drained for agricultural purposes. These agricultural impoundments were the first examples of structural marsh management in the Louisiana coastal zone. However, many of the early agricultural projects failed by 1915 . The weak, highly compressible, and organic soils within most of the impoundments were unstable, and levees were difficult to build and maintain. Forced drainage caused the soils to oxidize and consolidate and subsidence increased (Okey 1918). In a recent study, Turner and Neill (1983) reported that seven of 32 original tracts are still in agricultural production, while four are partly or entirely developed as urban areas; a few reverted back to wetlands, but most (18) became open water. Some are currently leased to duck-hunting clubs, and the state has incorporated others into its system of game management. Today, newly impounded wetlands are commonly used for rice and soybean farming in the Atchafalaya River Basin.

Aquacultural impoundments. The impounded area devoted to crawfish (primarily Procambrus spp.) aquaculture in southern Louisiana is increasing annually. Managed pond area is currently estimated to be 50,000 ha, up from 8,000 ha in 1970 (Day and others 1986). The increasing success of crawfish aquaculture can be attributed to research and agricultural extension services, as well as federal policies on agricultural subsidies. The commodity price squeeze has caused many rice farmers to double-crop rice fields with crawfish and to convert low-lying, marginal wooded areas (unsuitable for other crops and idled under subsidy programs) into crawfish ponds by impoundment. The largest acreage of crawfish ponds is located in the alluvial valley and on the prairie terrace, although there is substantial, but unknown, acreage in the coastal wetlands, primarily in backswamps and along fringing natural levees.

Fish and wildlife impoundments. Impoundments managed for the improvement of fish and wildlife habitats in Louisiana are best exemplified by the facilities at Rockefeller State Wildlife Refuge and Game Preserve located in the southwestern part of the state. Management strategies and practices used on the Refuge provide insight into other areas of the state (Wicker and others 1983a and b, Davidson and Chabreck 1983). 
Table 2. The area, by category, of coastal Louisiana impoundments up to 1978 (adapted from Day and others 1986; ( 1 ha $=2.47$ acres).

\begin{tabular}{lr}
\hline Impoundments category & Area (ha) \\
\hline Agricultural & 153,645 \\
Crawfish & 48,564 \\
Fish and wildlife & 118,198 \\
Urban & 34,435 \\
Unintentional-incomplete survey & 46,289 \\
Natural-incomplete survey & 2,918 \\
Unsuccessfula & 34,435 \\
Total & 438,484 \\
\hline
\end{tabular}

2 Original purpose of impounding not evident.

Intensive marsh management and impoundment began on the Refuge in the mid-1950s when it became evident that much of its 30,760 ha were undergoing widespread deterioration from alteration of natural drainage, severe animal grazing ("eat outs"), and drought (Wicker and others 1983a and b). Implementation of the management program was facilitated by oil and gas revenues, and the initial goals were to enhance wintering waterfowl habitat (Wicker and others $1983 a$ and b). Over the past 30 years, the Refuge management goals have expanded to accommodate multiuse purposes (especially fur-bearer production and increased fisheries). Structural marsh management techniques have improved with the knowledge gained from the Refuge's program.

The Refuge currently contains 17 management units, 13 of which are impoundments equipped with water control structures allowing varying degrees of manipulation of water level and hydroperiod. The original objective of each of these marsh management units was to enhance food supplies and resting areas to support large populations of wintering geese and waterfowl (Wicker and others 1983a). The present multiuse management objectives include preservation of habitat for the American alligator (Alligator mississippiensis), nongame birds, and fur-bearers, as well as the enhancement of aquatic habitats for estuarine organisms (Wicker and others 1983a and b, Davidson and Chabreck 1983).

Urban impoundments. Urbanized or developed impoundments are those wetland areas that have been "reclaimed" for urbanization or industrial purposes. The most striking example of an urbanized impoundment in Louisiana is the city of New Orleans. A historical overview of the growth of New Orleans is presented by Gagliano (1973). The high, stable, natural levees of the Mississippi River were settled first. The city then progressively expanded into the marsh by using an intricate drainage network (dikes, canals, ditches, and pumping stations), which was required to keep low-lying areas (many below sea level) adequately drained (Gagliano 1973).

Unintentional impoundments. Unintentional impoundments occur when canals, spoil banks, and road embankments interconnect, sometimes with natural features (that is, cheniers), to form impoundments or semi-impoundments. They have become more common as oil and gas access canal density increases and coastal zone development continues. The impoundments frequently lead to uncontrolled alterations (reduction) in overland flow hydrology, resulting in wetland loss and decreased primary productivity (Day and others 1986). Areas with high canal density and many impoundments often have high rates of land loss (Craig and others 1980, Scaife and others 1983, Turner 1985, Walker and others 1987).

\section{Impoundment Type by Function}

Managed, intentional impoundments can be divided into four major functional types (Wicker and others 1983a and b), which differ according to the extent that water level manipulation is possible. Each of these functional types may be used in one or more of the usage categories previously described where appropriate. These types are (a) passive estuarine, (b) controlled estuarine, (c) gravity drainage, and (d) forced drainage. The following evaluations of each functional impoundment type including its suitability for management of a target species, designated management techniques, and operations, are based on the information contained in Wicker and others (1983a and b), Davidson and Chabreck (1983), Davis and others (1983), Day and others (1986), and our own observations.

Passive estuarine. The primary management objective of passive estuarine impoundments (or semi-impoundments) is to stabilize their hydrologic regime through placement of low-level, fixed-crest (Wakefield) weirs (Figure 2A), although earthen plugs are sometimes used in the natural bayous or canals that drain the management areas. Weirs prevent dewatering of the impoundments during low tides or during the winter when prevailing winds drain the wetlands. In general, weirs are best suited for smaller impoundments and reduce tidal exchange and turbidity, stabilize water levels, and may increase aquatic vegetation production. Fixed-crest (Wakefield) weirs are usually set $15 \mathrm{~cm}$ ( 6 inches) below the marsh surface and anchored into the canal levee. Earthen plugs are less effective than weirs as permanent water control structures because they are easily eroded by pres- 

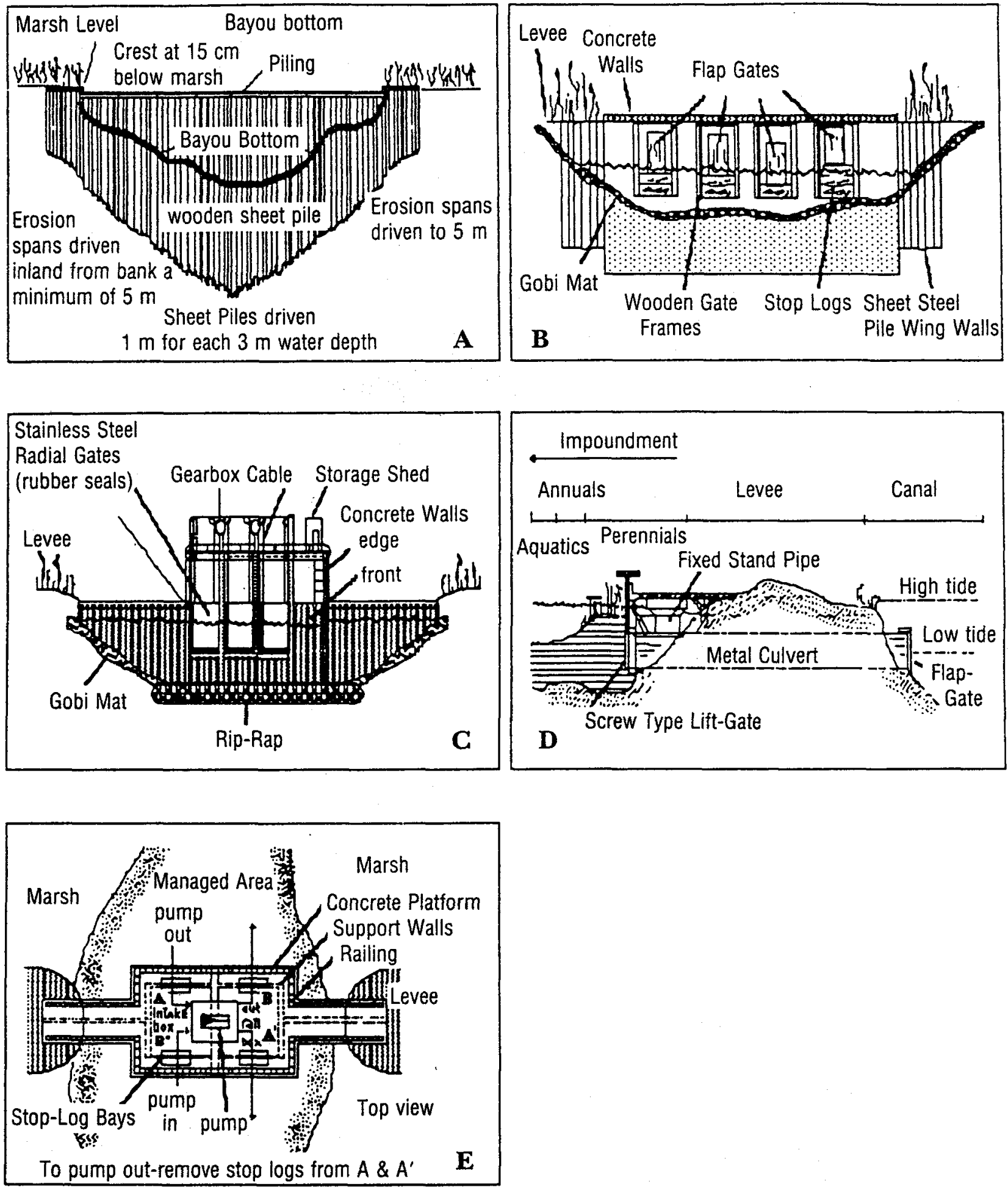

Figure 2. Schematic diagram of water control structures: (A) typical fixed crest (Wakefield) weir; (B) concrete, variable crest, reversible flap-gate control structure; (C) concrete and stainless-steel radial lift-gate control structure; (D) 36-inch flapgated metal culvert; and (E) double-divergent pumping unit. From Wicker and others 1983b. 
sure from the impounded water (Wicker and others $1983 \mathrm{a}$ and $\mathrm{b}$ ).

On the Rockefeller Refuge, passive estuarine impoundments are primarily managed for waterfowl and fur-bearer habitat, although they have been only marginally successful in producing waterfowl foods (Widgeon grass, Ruppia maritima) or preferred muskrat (Ondatra zibethicus) habitat and foods (three-cornered grass, Scirpus olneyi; dwarf spikerush, Eleocharis parvula) (Wicker and others 1983a and b). The marshes within these impoundments tend to break up over time and turn into open water. Encircling levees and weirs may contribute to marsh breakup and land loss by maintaining higher-than-normal water levels, which prohibit seed germination and growth of annuals, while placing stress on brackish perennials (Wicker and others 1983a and b). However, passive estuarine impoundments may be important nursery areas to many recreational and commercial estuarine-dependent fishery species (Herke 1979, Davidson and Chabreck 1983).

Controlled estuarine. The primary management objective of controlled estuarine impoundments is to manipulate water level and/or salinity routinely on a seasonal basis (Wicker and others 1983b). These impoundments, enclosed by levees that contain various types of water control structures, are designed to enhance productivity of estuarine vegetation and to improve fish and wildlife habitat. Control structures similar to those shown in Figure 2B (concrete variablecrest reversible flap-gate) and $2 \mathrm{C}$ (concrete and stainless-steel radial flap-gate) are usually set to discharge water during falling tides. The gates can be reversed to allow ingress of water and estuarine organisms during rising tides and/or periods of peak organism abundance (Davidson and Chabreck 1983, Wicker and others 1983a and b). Once the organisms are grown, they may emigrate from the management area when the flap-gates are discharging. Such water control structures must be well maintained to prevent leakage and should be as tamper-proof as possible (Wicker and others 1983b).

On the Rockefeller Refuge, controlled estuarine -impoundments serve as nursery areas for important recreational and commercial estuarine-dependent fish and crustaceans (Davidson and Chabreck 1983, Wicker and others 1983a). These impoundments can also be managed for increased waterfowl food production by drawing down water levels in the spring at three-year intervals. This allows the soft mud substrates to consolidate and compact. Upon reflooding, the dried surface crust is more resistant to resuspension by winds, thereby decreasing turbidity and pre- sumably increasing primary productivity and revegetation (Wicker and others 1983a).

Gravity drainage. Gravity drainage impoundments create a hydrologically self-contained management area where the primary source of flooding is precipitation. Consequently, flooding in these impoundments may be limited during drought. However, when water levels inside are high, surplus water can be discharged via gravity during low tides through control structures such as the flap-gated metal culvert shown in Figure $2 \mathrm{D}$.

On the Rockefeller Refuge, gravity-drained impoundments have been relatively successful as waterfowl management areas because they usually allow sufficient dewatering to produce substantial yields of waterfowl food (Wicker and others 1983a). This type of impoundment is also commonly used for crawfish aquaculture. Successful management of gravitydrained impoundments depends on sufficient precipitation at the proper time of year.

Forced drainage. The primary management objectives of forced drainage impoundments are to create hydrologically self-contained management areas (similar to gravity drainage), or reclaim wetlands for urban or industrial purposes. Water levels inside impoundment levees are controlled by the use of pumps and are not dependent on winds, tides, or precipitation. Many forced drainage impoundments use water control structures, such as double-divergent diesel- or gasoline-powered pumping units (Figure $2 \mathrm{E}$ ) to control hydroperiod. Stop-log bays and stop-logs allow water to exit or enter as the management strategy requires (Wicker and others 1983a and b). This type of impoundment provides the best control over water levels, salinity, and hydroperiod and usually results in consistent vegetation production from year to year. Forced drainage impoundments, however, are the most expensive to maintain and operate.

\section{Chenier Plain Impoundments}

\section{Chenier Plain Management}

Impounding coastal wetlands is a relatively common and traditional structural marsh management practice in the Chenier Plain. Marshes managed by impoundment are distinctive enough that Gosselink and others (1979) identified them as modified wetlands in their habitat characterization study. Impounded marshes comprise large areas of the Chenier, Mermentau, and Sabine hydrologic basins and constitute over $15 \%(100,000 \mathrm{ha})$ of the inland area of the Chenier Plain (Gosselink and others 1979) (Table 3).

Early impoundments were constructed by farmers 
Table 3. The area of impounded and semi-impounded land and open water in the Chenier Plain (adapted from data in Day and others 1986). The total study area is $\sim 600,000$ ha.

A. Impounded (ha).

\begin{tabular}{lrrrrrr}
\hline Land category & Area & \% Area & Number & Mean & Largest & Smallest \\
\hline Agricultural & 27,803 & 17.8 & 8 & 3,475 & 9,042 & 35 \\
Marsh, agricultural & 32,439 & 20.8 & 5 & 6,488 & 15,696 & 2,639 \\
Marsh & 691 & 0.4 & 1 & 691 & 691 & 691 \\
Spoil & 4,735 & 3.0 & 6 & 789 & 1,942 & 27 \\
Developed & & & & 148 & 148 & 166 \\
$\quad$ agriculture & 148 & 0.1 & 1 & 108 & 8,976 & 14 \\
Crawfish ponds & 325 & 0.2 & 3 & 2,640 & 90 \\
Reserves, private & 34,320 & 22.0 & 6,255 & 18,129 & 2,877 \\
Reserves, public & 55,530 & 35.6 & 43 & 3,628 & 18,129 & 2,877 \\
Total & 155,991 & 99.9 & & & &
\end{tabular}

B. Semi-impounded (ha).

\begin{tabular}{lcccr}
\hline Land category & Area & \% Area & Number & Mean size \\
\hline Marsh, agriculture & 11,349 & 25 & 1 & 11,349 \\
Marsh, open water & 13,478 & 29 & 2 & 6,739 \\
Marsh & 21,327 & 46 & 14 & 1,523 \\
Total & 46,154 & 100 & 17 & 2,715 \\
\hline
\end{tabular}

who built levees around their fields to keep water out. After discovering that impoundments were too expensive to maintain, the farmers abandoned them and the impoundments became shallow lakes. Management of continuously flooded areas for waterfowl hunting began with these abandoned agricultural impoundments (Ensminger 1963). In more recent years (1930s to present), impoundments were constructed as land reclamation or maintenance projects, primarily by the oil and gas industry to protect subsurface mineral leases. During this same time period, however, increasing oil and gas exploration and development in the coastal wetlands, along with associated dredge, fill, and extraction activities, resulted in increased subsidence, land loss, and habitat change in the Chenier Plain (Gosselink and others 1979, Turner and others 1982, Turner 1985, Alexander 1985). Consequently, many impoundments, which have been recently constructed in the Chenier Plain or are currently proposed, are part of formal MMPs designed to slow land loss and improve wildlife and fishery habitats.

Although marsh impoundments have been used in the Chenier Plain to improve wildlife and fishery habitats (Chabreck and others 1978, Gosselink and others 1979), there is little evidence currently available to suggest that they are effective in reducing land loss rates. The probability is that without improved water level control, unusually wet or dry years will result in poor quality food production (vegetation) for wildlife (Wicker and others 1983a and b, T. Joanen personal communication $\left.^{3}\right)$. In addition, there is often little interaction between the impoundment and the surrounding ecosystem because water exchange is retarded by levees or water control structures. Valentine (1978) suggested that impoundments in intermediate to fresh environments impede saltwater intrusion (a temporal or spatial shift in average isohalines), which has been associated with vegetation die-backs that reportedly lead to land loss. However, there is some evidence to suggest that environmental problems may arise when impoundments isolate the marsh and inhibit its function as part of a regional riverine or estuarine system, particularly in areas that are normally within the tidal prism. These problems include (a) creating a barrier to the transport of estuarine-dependent fish and crustaceans into management areas (Herke 1979, Rogers and others 1987), (b) decreased input of sediments, nutrients, and water, and (c) alteration of on-site water chemistry, nutrient cycles, vegetation, and flood storage capacity (Chabreck and others 1978).

\section{Management Results at Rockefeller Refuge}

On the Rockefeller Refuge, maximum success of all four functional impoundment types has been related to meteorological conditions. Successful management requires the ability to adjust to both natural and manmade environmental conditions that adversely affect productivity and long-term management goals. Consequently, management objectives must be related to ex- 
isting environmental conditions and designed not to overmanage or overcommit resources, while simultaneously incorporating knowledge of the biology of the target species (for example, water level requirements, salinity preferences, and/or vegetation requirement of fish and wildlife species) and maximizing habitat area for compatible species. However, it has been impossible to manage the same area for all species since many management practices are selective (Wicker and others 1983b); for instance, a management strategy that is beneficial to alligators and fur-bearers may adversely affect estuarine-dependent fish and crustaceans. Furthermore, the overall recent trend of vegetation cover in the Refuge has been decreasing marsh and increasing open water. Between 1930 and 1979, the land-water ratio changed from $91: 9$ to $78: 22$, respectively. Marsh breakup is most severe in brackish interior marshes where there is little active water level management (Wicker and others 1983b).

Marsh Management and Landloss:

Quantitative Relationships

At present, it is difficult to quantify the effectiveness of MMPs at combatting land loss because there is little long-term data to analyze. The required monitoring of the environmental effects of structural marsh management practices in Louisiana was initiated only recently (1980). Both the CMD/LDNR and SCS have identified a need for more premanagement environmental data collection and analyses in proposed MMPs (D. Clark personal communication, M. Matherne personal communication). In addition, monitoring reports following implementation have proven to be relatively ineffective at accurately assessing environmental conditions within the management area. Much of the information provided in the monitoring reports is based on visual inspection and interpretation of environmental conditions in the management area rather than experimentally generated results. There is usually no systematic collection and evaluation of scientific data. Furthermore, many land managers either do not file monitoring reports or provide incomplete data that merely consist of long lists of salinities and/or water levels (D. Clark personal communication). Consequently, the resulting data are of poor quality and insufficient to assess land loss quantitatively within the impounded areas. However, there is some evidence to suggest that impounding wetlands may increase land loss rates within managed areas because of hydrologic isolation from their surroundings (Chabreck and others 1978, Day and others 1986) and that long-term cumulative effects caused by the alteration of ecosystem hydrology may be significant (Gosselink and others 1979, Turner 1985). At present construction and land loss rates, about $30 \%-40 \%$ of the coastal wetlands will be impounded and $25 \%$ of existing wetlands lost by the year 2020. Therefore, the development of a quality data base seems imperative if the management implications of MMPs are to be properly evaluated and informed decisions made concerning the use of impoundments in marsh management planning.

Even though the number of CUP applications for MMPs filed with the CMD/LDNR since 1982 has remained relatively low and constant compared with total permit requests (Table 4), their impact on the coastal zone is potentially great because of their large size $($ mean $=1529 \mathrm{ha})$. Clearly, more quantitative studies before and following implementation of MMPs that include structural management practices are needed to determine the relationship of management to land loss rates in Louisiana's coastal zone.

\section{Marsh Management in Practice}

We conducted a detailed examination of the relative success of impoundments in MMPs in the Chenier Plain using relevant information on land loss as well as interviews with Louisiana state and US government officials, private consultants, and private and corporate landowners. Interviewees were asked to address the following issues: (1) the goals and reasons for marsh management in the Chenier Plain; (2) whether impoundment, specifically, and marsh management, in general, works to control land loss and enhance productivity in coastal wetlands; (3) the pros and cons of the permitting process; and, (4) changes in state policy regarding management practices.

\section{Resuits from Interviews}

The following information summarizes the results obtained from a series of interviews conducted between 18 August and 8 September 1986. The persons interviewed were knowledgeable of, and had acute interest in, marsh management practices in the Chenier Plain. Persons representing the following concerns were interviewed:

\section{State of Louisiana}

Louisiana Department of Natural Resources, Coastal Management Division

Louisiana Department of Wildlife and Fisheries, Refuge Division

Soil and Water Conservation Committee

US Government

Fish and Wildlife Service, Refuge Division 
Table 4. Total permit applications and issuances of the Louisiana Coastal Management Division from 1981 to 1985 ( 1 ha $=2.47$ acres).

A. Permit number and area.

\begin{tabular}{|c|c|c|c|c|}
\hline \multirow[b]{2}{*}{ Year } & \multirow[b]{2}{*}{$\begin{array}{c}\text { Total } \\
\text { applications }\end{array}$} & \multirow{2}{*}{$\begin{array}{c}\text { Permits } \\
\text { issued } \\
\text { (no.) }\end{array}$} & \multicolumn{2}{|c|}{$\begin{array}{c}\text { Marsh } \\
\text { management plans }\end{array}$} \\
\hline & & & $\begin{array}{l}\text { Permitted } \\
\text { (no.) }\end{array}$ & $\begin{array}{l}\text { Area } \\
\text { (no.) }\end{array}$ \\
\hline 1981 & 1986 & 824 & 6 & 998 \\
\hline 1982 & 1544 & 505 & 20 & 40,013 \\
\hline 1983 & 1355 & 495 & 33 & 53,796 \\
\hline 1984 & 1680 & 742 & 12 & 30,555 \\
\hline 1985 & 1533 & 784 & 20 & 13,817 \\
\hline Total & 8098 & 3350 & 91 & 139,179 \\
\hline
\end{tabular}

B. Marsh management plans by habitat from 1981 to 1985 .

\begin{tabular}{lcrr}
\hline Habitat & Number & Area (ha) & $\%$ Total \\
\hline Saline & 3 & 7,611 & 5 \\
Brackish, saline & 3 & 11,729 & 7 \\
Brackish & 19 & 25,354 & 18 \\
Intermediate & 5 & 3,114 & 2 \\
Fresh, intermediate & 4 & 5,995 & 4 \\
Fresh & 20 & 68,309 & 49 \\
Swamp & 9 & 5,770 & 4 \\
Unknown habitat & & & \\
$\quad$ or area & 28 & 11,297 & 8 \\
Total & 89 & 138,980 & $97^{\mathrm{a}}$ \\
\hline
\end{tabular}

2 Does not $=100$ because of rounding errors.

Department of Agriculture, Soil Conservation Service

Department of the Interior, Louisiana Cooperative

Fishery Research Unit

Private consulting interests

Lonnie Harper and Associates, Inc.

Paul Coreil, Fisheries and Wildlife Biologist

Private and corporate landowners

Amoco Production Company

Miami Land Corporation

Continental Land and Fur

Little Pecan Properties

John Paul Crane, Inc.

At least one representative from each concern was asked to respond to specific questions regarding marsh management goals, the permitting process, and current management policies. The following is a compilation of their responses. Specific differences in opinion are noted.

Goals and reasons for marsh management in the Chenier Plain. As expected, the state's response to questions of goals closely followed the LCRP guidelines outlined earlier in this article. Overall, structural marsh management practices in the Chenier Plain are designed to enhance the primary and secondary productivity of impounded wetlands and, where possible, to restore deteriorating coastal marshes through the implementation of well-prepared management plans and $\mathrm{CMD} /$ LDNR-approved practices. A realization of these goals is intended to result in increased and enhanced wildlife and fishery habitat and retarded coastal land loss through revegetation and restoration of unhealthy areas. People interviewed (landowners in particular) identified "the control of saltwater intrusion" and associated marsh die-backs and land loss as a primary objective of, and reason for, marsh management planning in the Chenier Plain. The complementary objectives mentioned above (habitat enhancement and increased productivity) were of secondary importance. Although there is little quantitative evidence to support the landowner's concern, recent studies attribute high land loss rates in much of the Chenier Plain to altered hydrology coupled with saltwater intrusion (Adams and others 1978, Gosselink and others 1979, Alexander 1985).

As a whole, the Calcasieu-Sabine Basins have the highest land loss rates in the Chenier Plain (Adams and others 1978). A primary hydrologic alteration there was the dredging of a deep navigation (shipping) channel in Calcasieu Lake in the Calcasieu Basin in the mid-1940s. This shipping channel captured the main flow of fresh water from the Calcasieu River which, during periods of peak discharge, circulated throughout the Basin (Alexander 1985). The deep channel now acts as a "salt pump" and brings more saline waters to reach farther inland (Alexander 1985). As a result, salinity has increased in Calcasieu Lake and the surrounding marshes (Van Sickle 1977), and sediment and nutrient deficiencies have contributed to marsh deterioration (Michot 1984). The Gulf Intracoastal Waterway and other canals, primarily constructed for the oil and gas industry, have also altered hydrology in the Chenier Plain and are believed to have added to saltwater intrusion problems in the area (Gosselink and others 1979, Alexander 1985).

Both landowners and state regulatory personnel are trying to implement marsh management to control saltwater intrusion and maintain isohalines and associated marsh vegetation patterns at their current configurations. Changes in marsh vegetation types, assumed to be in response to changing isohalines, have been dramatic in the Chenier Plain since the late 1940s (Louisiana Department of Public Works 1949, Chabreck and others 1968, Chabreck and Linscombe 1978). The inland extent of saline marshes has in- 
creased from 1949 to 1978. Consequently, implemented or proposed MMPs in the Chenier Plain are primarily designed to maintain existing salinity patterns and vegetative conditions and secondarily to restore and enhance the productivity of managed wetland areas. This dichotomy has affected the success of permits for MMPs in the Chenier Plain caused by disagreement between potential marsh managers (landowners) and the state's regulatory agencies.

Structural marsh management in the Chenier Plain. As a final evaluation of marsh management planning in the Chenier Plain, all persons interviewed were asked to respond to the following question: Does marsh management in general, and the impoundment of coastal wetlands in particular, produce the desired results of land loss reduction and enhancement of wetland productivity in the Chenier Plain? The answer was a "qualified" yes. However, most interviewees acknowledged that there is little quantitative data available to support that conclusion.

The success of marsh management in the Chenier Plain generally appears to be inversely related to salinity and positively influenced by an increase in active versus passive management strategies. Consequently, this may be why a high percentage of managed impoundments (55\% of impounded area) occur in fresh and intermediate marshes relative to the area of these marsh types in the Chenier Plain and statewide (Table 4). Impounded fresh and intermediate marshes appear to do relatively well when hydrologically isolated from their surroundings as they are typically outside of any tidal influence and derive much of their moisture from precipitation. These impounded marshes are usually managed for wildlife and waterfowl and may produce high-quality food plants for wildlife. Fresh and intermediate marsh impoundments may be maintained in areas surrounded by brackish and/or salt marshes by using intensive, active management (for example, pumping, forced drainage).

Land loss rates in the Chenier Plain and statewide are highest in brackish and saline marshes. Although brackish and saline marshes account for approximately $62 \%$ of the coastal wetlands in Louisiana, they contain only $30 \%$ of the area currently impounded (Table 4). In the Chenier Plain, impounded brackish marshes are only marginally successful in producing habitat suitable for wildlife and waterfowl under passive structural management conditions (fixed-crest weirs, dams, earthen plugs) and are relatively unsuccessful in controlling land loss. In some cases, land loss rates within the impoundments may increase due to hydrologic isolation in an otherwise tidally influenced area. Marshes in these impoundments tend to break up and die back to form open water. However, brackish marshes that are actively managed by using versatile water control structures (variable-crest and vertical-slotted weirs, radial lift gates, flap-gated culverts) (see Figure 2) may be maintained, and in some cases revegetated, particularly where complete and regular water drawdown (every three years) is possible. Therefore, a more active (forced or gravitydrained) approach to marsh management may work in these areas to control or slow land loss rates. However, brackish marsh impoundments may be important nursery areas for commercially important estuarinedependent fish and crustacean species and management plans must be developed with this in mind; available data indicate that water control structures decrease estuarine accessibility (Rogers and others 1987). Therefore no management might work even better. In saline marsh environments, marsh management using structural modifications has seen little success and only $5 \%$ of the total managed impoundment area occurs in saline marshes (Table 4).

These findings support those from other regions of the state that show that marsh management by using structural modification to influence water level (impounding) is, at best, marginally or partially successful in controlling saltwater intrusion or land loss rates and in enhancing productivity in coastal wetlands in Louisiana (Table 5). The most successful methods appear to be the most expensive. Vegetation composition, as well as other ecological parameters, may be influenced by structural approaches, but long-term data are not generally available for analysis. Overall, the best results may be obtained in fresh and intermediate marsh environments. However, relative to the salt marsh, current landloss rates are less severe in fresh marsh areas.

The permitting process in practice. A potential source of conflict between the applicant and the regulatory agencies in the development of MMPs derives from the confusion over which mandate, goals, and policies are to take precedent in any given situation. A MMP is often developed by concensus at a meeting of agency representatives and the applicant. This can be a timeconsuming and confusing process for the applicant, since he must satisfy many regulatory mandates besides those of the two agencies that issue the permits. A strong negative evaluation from any of the commenting agencies can influence the CMD/LDNR permitting process. In the Chenier Plain, this concern is highlighted by the conflict between landowners and regulatory personnel over the control of saltwater intrusion versus the accessibility of impounded wetlands to estuarine organisms. Control of land loss (reduced saltwater intrusion) and enhancement of productivity 
Table 5. General summary of results of structural marsh management practices (impoundments) as determined in this and other studies.

\begin{tabular}{|c|c|c|}
\hline $\begin{array}{l}\text { Ecological } \\
\text { manipulation }\end{array}$ & Success rate & Reference/example \\
\hline Water level control & $\begin{array}{l}\text { Unintentional in many passive schemes; harmful in some } \\
\text { unintentional impoundments; very successful in some } \\
\text { management programs. }\end{array}$ & $\begin{array}{l}\text { Swenson and Turner (1987) } \\
\text { Turner and Neill (1983) } \\
\text { Wicker and others (1983a } \\
\text { and b) }\end{array}$ \\
\hline Salinity & $\begin{array}{l}\text { Low in brackish and saline marsh; possible in fresh } \\
\text { marshes; somewhat less variable than in natural systems. }\end{array}$ & $\begin{array}{l}\text { Day and others (1986) } \\
\text { Wicker and others (1983a } \\
\text { and b) } \\
\text { Davidson and Chabreck } \\
\quad(1983)\end{array}$ \\
\hline Turbidity & $\begin{array}{l}\text { Not clear. Shallow impoundments subject to wind have } \\
\text { increased turbidity; there is less turbidity behind weirs, } \\
\text { and in more saline impoundments; some studies } \\
\text { document no difference between sites with and without } \\
\text { weirs. }\end{array}$ & $\begin{array}{l}\text { Day and others (1986) } \\
\text { Wicker and others (1983a } \\
\text { and b) } \\
\text { Davidson and Chabreck } \\
\quad(1983)\end{array}$ \\
\hline Migration access by organisms & Low (restricted in all areas). & $\begin{array}{l}\text { Herke (1979) } \\
\text { Neill and Turner (1986) }\end{array}$ \\
\hline Landloss rate reduction & $\begin{array}{l}\text { Not clear. Increased rates in many marshes due to indirect } \\
\text { effects; many impounded marshes (intentional and } \\
\text { unintentional) turn to open water. }\end{array}$ & $\begin{array}{l}\text { Scaife and others (1983) } \\
\text { Turner and Neill (1983) } \\
\text { Day and others (1986) }\end{array}$ \\
\hline Vegetation quality & Low in salt marsh; low to high in fresh marsh. & $\begin{array}{l}\text { Wicker and others (1983a } \\
\text { and b) }\end{array}$ \\
\hline
\end{tabular}

(estuarine accessibility) are two goals of a statewide coastal resources management program whose attainment is viewed by landowners and some agency personnel as somewhat mutually exclusive in the Chenier Plain. In recent years, MMP permit applications have reportedly been deferred for long periods of time (two years or more) by the CMD/LDNR, based largely on negative evaluations from mission-oriented agencies. We were told that several permit requests for MMPs developed primarily to control saltwater intrusion were eventually withdrawn by the landowner after extraordinarily long delays. These MMPs reportedly limited access of commercially important estuarine-dependent organisms to impounded nursery areas. The landowners we interviewed see this as "narrow-minded management from afar" by regulatory personnel not adequately familiar with the problems specific to marsh management in the Chenier Plain.

In a related matter, the MMP must include a detailed schedule for opening and closing water control structures to allow estuarine accessibility during times of peak organism abundance. This is a highly selective practice since many species do not peak in abundance during the same time and regulating for one might adversely impact others (Rogers and others 1987). CUP approval is often delayed for considerable periods of time (six months to two years) while justifiably concerned regulatory personnel determine water control schedules best suited for realization of both management goals (land loss control and productivity enhancement). However, most landowners feel this to be a "cookbook" approach that is inflexible, time consuming, and difficult to adjust to when environmental conditions and species abundance peaks vary from year to year.

The landowners interviewed here generally agreed that some regulatory function must exist in Louisiana's coastal zone but that the CMD/LDNR permitting process is often too expensive, bureaucratic, and slow, requires too much interagency agreement, and may hinder marsh management (Table 6). Most also believe that MMPs developed without some professional assistance (private consultants) stand little chance of permit approval because of the complexity of current management issues in Louisiana. Many small private landowners cannot afford consulting fees. The SCS is available free of charge to assist landowners in preparing MMPs on a first-come first-serve basis, but in many high-demand areas (for instance, the Chenier Plain) there can be as much as a two-year waiting period. The state regulatory agencies are generally understaffed and work loads are heavy (Turner and others 1983). Management problems specific to different regions of the Louisiana coast, like those dis- 
Table 6. Issues related to marsh management plans identified by private and public agencies during interviews.

\begin{tabular}{|c|c|c|}
\hline Phase & Permittee concerns & Public agency concerns \\
\hline $\begin{array}{l}\text { Preparation of } \\
\text { plan }\end{array}$ & $\begin{array}{l}\text { Time consuming } \\
\text { Costs, especially for small operators } \\
\text { Complicated and new } \\
\text { Unpredictable review } \\
\text { Delays } \\
\text { Conflicting aims of permitting agencies } \\
\text { Lack of written material on what MMP can/cannot } \\
\text { do } \\
\text { Long-term experience absent }\end{array}$ & $\begin{array}{l}\text { Understaffed } \\
\text { Conflicting multiuse responsibilities } \\
\text { Unclear guidelines } \\
\text { Staff turnover } \\
\text { Too little information in plans or on the area, in } \\
\text { general } \\
\text { Cumulative impacts are extremely difficult to } \\
\text { measure/predict } \\
\text { Marsh management myths (unsubstantiated policies) } \\
\text { Long-term experience absent } \\
\text { Lack of scientific data/analysis }\end{array}$ \\
\hline $\begin{array}{l}\text { Implementation } \\
\text { of plan }\end{array}$ & $\begin{array}{l}\text { Unpredictable weather may damage construction } \\
\text { Increased costs due to delays } \\
\text { Modification of plans difficult at this phase }\end{array}$ & Too understaffed to check on construction \\
\hline Monitoring & $\begin{array}{l}\text { Repetitious measurements required but are } \\
\text { meaningless without analysis } \\
\text { In light of above, the monitoring seems less like } \\
\text { monitoring and more like paperwork }\end{array}$ & $\begin{array}{l}\text { Little or no follow-up on site or of data turned in } \\
\text { No long-term data analysis possible }\end{array}$ \\
\hline
\end{tabular}

cussed above for the Chenier Plain; vary and require individual consideration, but agency assistance is apparently not equal to demand.

Evolution of management policies and practices. We asked the Coastal Management Division to address some of the land loss issues described above, especially the concerns of the landowners in the Chenier Plain. Although the landowners offered few suggestions for improvement, the CMD/LDNR was familiar with, and sensitive to, management issues in the Chenier Plain and their own (CMD) probable shortcomings. They stated that understaffing, rather than a lack of expertise, sensitivity, and desire regarding marsh management, was a key area of concern in Louisiana state government.

The CMD/LDNR is striving to address marsh management issues in the Chenier Plain and statewide by (a) identifying potential areas of concern for future study, and (b) developing procedures that will assist landowners in developing MMPs consistent with the LCRP goals of land loss control and productivity enhancement. A draft Marsh Management Manual has been completed by the Soil Conservation Service (SCS) jointly with CMD/LDNR, which includes technical guidelines for structural marsh management practices. The manual is intended to be used by CMD/LDNR, SCS, and other agency personnel, as well as landowners and others involved in marsh management planning activities that may result in the CUP application. The following list contains some other pertinent and potential areas of concern, changes in state policy or actions, and areas of future study regarding marsh management practices in Louisiana's coastal zone as identified by the CMD/LDNR:

1) Information concerning marsh management practices, wetland restoration, and land loss control techniques that are consistent with LCRP goals should be distributed to more coastal landowners, consultants, and agencies.

2) An inventory of existing MMPs and structures is needed to determine possible cumulative effects of these activities on the coastal zone. Little definitive data on cumulative effects in the Chenier Plain and statewide are currently available. Selected existing management plans should be monitored to determine whether the goals of the plans are being achieved.

3) Engineering techniques need to be continuously developed to design and construct water control structures that are able to both control water levels and allow unrestricted movement of estuarine-dependent organisms. This dual purpose is of particular interest in the Chenier Plain. The Louisiana State University School of Forestry, Wildlife and Fisheries, in conjunction with the CMD/LDNR, has recently performed a study comparing the design of fixed-crest weirs with that of a newly developed vertically slotted weir that will allow better access by estuarine-dependent organisms to impounded wetlands (Rogers and others 1987).

4) The effects of newly designed water control structures should be compared experimentally 
with natural areas and areas with older water control structures to determine the degree of organism movement, water level control, wildlife benefits, and land loss for each type of new structure. Regulatory agencies would be able to better review MMPs to determine whether the goals of their programs were being achieved by the structures in the plans.

In summary, MMPs employing impoundments have been implemented in the Chenier Plain's coastal wetlands despite three problem areas: (a) the problems inherent in a large-scale regulatory program, (b) the conflicts between regulatory personnel and landowners, and (c) potential changes in Louisiana state marsh management policy.

\section{Conclusions}

An evaluation of current information indicates that impoundments are, at best, marginally or partially successful in controlling saltwater intrusion or land loss rates and in enhancing productivity in coastal wetlands. Best results may be obtained in fresh and intermediate marsh habitats and the most successful impoundment methods appear to be the most expensive. However, our ability to make the best management decision/policy concerning the use of impoundments is limited by a most conspicuous absence of data collection and scientific analysis in virtually all the MMPs we examined. This is bothersome because in Louisiana the pace of change is high and the consequences of management are great. From where is this data, analysis, and policy synthesis to come? Social institutions each have their peculiar strengths and weaknesses in natural resource management issues. Clearly, regulatory agencies cannot duplicate the scientific research community, at least not easily, and the research community cannot regulate, nor should attempt to do so. The research community is clearly capable of addressing these issues. For example, the reference list in this report, though perhaps biased, is almost entirely based on results from the university research community, funded from a variety of state and federal sources. Regulatory personnel are not well represented in generating primary information; however, they are skilled at dealing with the various social institutions being regulated and protected. Federal agencies often have a broader mandate than local and state agencies, but less local influence. It is the challenge for addressing the management issues discussed herein to mix efforts cooperatively in both regulation and research communities. Regulation without skilled analysis to guide interpretation is foolhardy and a waste of money, as is duplicating each other's skills.

\section{Acknowledgments}

This analysis was made possible through the assistance of Jami Donley, Susan Hamilton, Barbara Keeler, Lee Wilson, and Wytze Hoekstra in helping with data analysis, preparation, and editing. Gwendolyn Redditt and Lee Lian Foong typed the manuscript. Our most sincere thanks go to the many people interviewed. W. Conner provided Figure 1. Funding was provided by the Louisiana Sea Grant Program to RET, the US Environmental Protection Agency, and Lee Wilson and Associates, Inc.

\section{Notes}

1. Louisiana Department of Natural Resources, Coastal Management Division, PO Box 941224, Baton Rouge, LA 70804.

2. US Department of Agriculture, Soil Conservation Service, Room 215, PO Building 123, East 3rd Street, Crowley, LA 70526.

3. Rockefeller Wildlife Refuge and Came Preserve, Route 1, Box 208, Grand Chenier, LA 70643.

\section{Literature Cited}

Adams, R. D., P. J. Banas, R. H. Baumann, T. H. Blackmon, Jr., and W. G. McIntire. 1978. Shoreline erosion in coastal Louisiana: inventory and assessment. Louisiana Department of Transportation and Development, Baton Rouge, Louisiana, 139 pp.

Alexander, C. E. 1985. An examination of habitat changes in the Calcasieu Basin of Louisiana using an automated geographic information system. Draft Report, National Coastal Ecosystems Team, US Fish and Wildlife Service, Slidell, Louisiana, 36 pp.

Chabreck, R. H., and G. Linscombe. 1978. Vegetative type map of the Louisiana coastal marshes. Louisiana Department of Wildlife and Fisheries, New Orleans, Louisiana.

Chabreck, R. H., R. J. Hoar, and W. D. Larrick, Jr. 1978. Soil and water characteristics of coastal marshes influenced by weirs. Pages 127-146 in J. W. Day, Jr. (ed.), Proceedings of the third coastal marsh and estuary management symposium. Louisiana State University, Baton Rouge, Louisiana.

Chabreck, R. H., T. Joanen, and A. W. Pamisano. 1968. Vegetative type map of the Louisiana coastal marshes. Louisiana Wildlife and Fisheries Commission, Louisiana Department of Wildlife and Fisheries, New Orleans, Louisiana.

Clark, D. R., D. R. Cahoon, J. L. Lindsey, and T. R. Osborn. 1983. A review of the Louisiana Coastal Resources Program from 1980-1983. Pages 157-169 in R.J. Varnell (ed.), Proceedings of the water quality and wetland management conference, New Orleans, Louisiana. 
Coleman, J. M. 1976. Deltas: Processes of deposition and models for exploration. Continuing Education, Champaign, Illinois, $102 \mathrm{pp}$.

Craig, N. J., R. E. Turner, and J. W. Day, Jr. 1980. Wetland losses and their consequences in coastal Louisiana. Zeitschrift für Geomorphologie [Suppl.] 34:225-241.

Davidson, R. B., and R. H. Chabreck. 1983. Fish, wildlife, and recreational values of brackish marsh impoundments. Pages 89-114 in R. J. Varnell (ed.), Proceedings of the water quality and wetland management conference, New Orleans, Louisiana.

Davis, D. W. 1973. Louisiana canals and their influence on wetland development. PhD dissertation, Louisiana State University, Baton Rouge, Louisiana, 199 pp.

Davis, D. J., D. W. Roberts, and K. M. Wicker. 1983. Components and controlling principles of coastal wetland management. Pages 41-66 in R. J. Varnell (ed.), Proceedings of the water quality and wetland management conference, New Orleans, Louisiana.

Day, J. W., Jr., and N. J. Craig. 1982. Comparison of the effectiveness of management options for wetland loss in the coastal zone of Louisiana. Pages 232-239 in D. F. Boesch (ed.), Proceedings of the conference on coastal erosion and wetland modification in Louisiana: causes, consequences and options. US Fish and Wildlife Service, Biological Service Program, Washington, DC, FWS/OBS-82/59.

Day, J. W., Jr., R. Costanza, K. Teague, N. Taylor, G. P. Kemp, R. H. Day, and R. E. Becker. 1986. Wetland impoundment: a global survey for comparison with the Louisiana coastal zone. Final report, Geological Survey Division, Louisiana Department of Natural Resources, 140 pp.

Ensminger, A. B. 1963. Construction of levees for impoundments in Louisiana marshes. Proceedings of the Annual Conference Southeastern Association of Game and Fish Commissioners 11:114-119.

Fisk, H. N. 1960. Recent Mississippi River sedimentation and peat accumulation. In Fourth international congress carboniferous stratigraphy and geology, Heerlen, Holland, 1958. Compte Rendu 1:187-199.

Frazier, D. E. 1967. Recent deltaic deposits of the Mississippi River: their development and chronology. Transactions of the Gulf Coast Association of Geological Societies 17:287-315.

Gagliano, S. M. 1973. Canals, dredging, and land reclamation in the Louisiana coastal zone. Hydrologic and geologic studies, report 14. Center for Wetland Resources, Louisiana State University, Baton Rouge, Louisiana, 104 pp.

Gagliano, S. M., K. J. Meyer-Arendt, and K. M. Wiçer. 1981. Land loss in the Mississippi River deltaic plain. Transactions of the Gulf Coast Association of Geological Societies 31:295-300.

Gosselink, J. G., C. L. Cordes, and J. W. Parsons. 1979. An ecological characterization of the Chenier Plain coastal ecosystem in Louisiana and Texas, vol. 1 US Fish and Wildlife Service, Biological Services Program, Washington, DC, FWS/OBS-78/09, 302 pp.

Herke, W. H. 1979. Some effects of semi-impoundment on coastal Louisiana fish and crustacean nursery usage. Pages 325-346 in J. W. Day, Jr., D. D. Culley, Jr., R. E. Turner, and A. J. Mumphrey, Jr. (eds.), Proceedings of the third coastal marsh and estuary management symposium. Loui- siana State University Division of Continuing Education, Baton Rouge, Louisiana.

Louisiana Coastal Resources Program. 1980. Final environmental impact statement (FEIS). NOAA Office of Coastal Resource Management and the Louisiana Department of Natural Resources, Washington, DC, and Baton Rouge, Louisiana, 190 pp. + appendices.

Louisiana Department of Public Works. 1949. Map of the southern part of Louisiana showing vegetation types of the Louisiana marshes. LDPW, Baton Rouge, Louisiana.

Mager, A., Jr., and L. H. Hardy. 1986. National Marine Fisheries Service Habitat conservation efforts in the southeast region of the United States for 1985. NMFS, Habitat Conservation Division, St. Petersburg, Florida.

Michot, T. C. 1984. Louisiana coastal area study, interim report on land loss and marsh creation: planning aid report. US Army Corps of Engineers, New Orleans, Louisiana, 45 pp.

Neill, C., and R. E. Turner. 1986. Comparisons of fish communities in open and plugged backfilled canals in Louisiana coastal marshes. North American Journal of Fisheries Management 7:57-62.

Okey, C. W. 1918. The subsidence of muck and peat soils in southern Louisiana and Florida. Paper no. 1410. Transactions of the American Society of Civil Engineers: 397-432.

Price, W.A. 1954. Environment and formation of the Chenier Plain. Quarternia 2:75-86.

Rogers, B. D., W. H. Herke, and E. E. Knudsen. 1987. Investigation of a weir-design alternative for coastal fisheries benefits. Final report, Louisiana Cooperative Fish. Research Unit, School of Forestry, Wildlife and Fisheries, Louisiana State University, Baton Rouge, Louisiana, 98 pp.

Scaife, W., R. E. Turner, and R. Costanza. 1983. Coastal Louisiana recent land loss and canal impacts. Environmental Management 7:433-442.

Spicer, B. E., D. R. Clark, and J. De Mond. Marsh management and the Louisiana Coastal Resources Program, 31 pp. (unpublished manuscript).

Swenson, E. M., and R. E. Turner. 1987. Spoil banks: effects on a coastal marsh water level regime. Esiuarine, Coastal and Shelf Science 24:599-609.

Turner, R. E. 1985. Coastal land loss, canals, and canal levee relations in Louisiana. US Fish and Wildlife Service Report 85(14), $58 \mathrm{pp}$.

Turner, R. E., and J. G. Gosselink. 1975. A note on standing crops of Spartina alterniflora in Texas and Florida. Contributions in Marine Science 19:113-118.

Turner, R. E., and C. Neill. 1983. Revisiting the marsh after 70 years of impoundment. Pages $309-32$ in $\mathrm{R}$. J. Varnell (ed.), Proceedings of the water quality wetland management conference, New Orleans, Louisiana.

Turner, R. E., R. Costanza, and W. Scaife. 1982. Canals and wetland erosion rates in coastal Louisiana. Pages 73-84 in D. F. Boesch (ed.), Conference on coastal erosion and wetland modification in Louisiana: causes, consequences, and options. US Fish and Wildlife Service, Biological Services Program, Washington, DC, FWS/OBS-82/59.

Turner, R. E., S. M. Peterman, and J. H. Cowan, Jr. 1983. Louisiana's infrastructure for natural resource manage- 
ment as compared to other states. Pages $141-156$ in R. J. Varnell (ed.), Proceedings of the water quality and wetland management conference, New Orleans, Louisiana.

Valentine, J. M., Jr. 1978. Plant succession after saw-grass mortality in southwestern Louisiana. Proceedings of the Annual Conference Southeastern Association of Game and Fish Commissioners 13:634-640.

Van Sickle, V. R. 1977. Coastal Louisiana-oyster distribution and ecological change. Louisiana State University, Center for Wetland Resources Temporary Document, LSU-SGTD2-76 (T).

Walker, H. J., J. M. Coleman, H. H. Roberts, and R. S. Tye.
1987. Wetland loss in Louisiana. Geografiska Annaler 69(A):189-200.

Wicker, K. M., D. J. Davis, and D. W. Roberts. 1983a. Marsh management techniques employed on the Rockefeller Refuge, Louisiana. Pages 67-88 in R. J. Varnell (ed.), Proceedings of the water quality and wetland management conference, New Orleans, Louisiana.

Wicker, K. M., D. J. Davis, and D. W. Roberts. 1983b. Rockefeller State Wildlife Refuge and Game Preserve: evaluation of wetland management techniques. Coastal Management Division, Louisiana Department of Natural Resources, Baton Rouge, Louisiana. 